\title{
Aporofobia: zaharrak berri? Kontzeptuaren bilakaera eta gainditzeko estrategien bila; hezkuntzarentzako erronka
}

\author{
Ane Ferran Zubillaga \\ Gizarte Laneko eta Soziologiako Departamentua, Deustuko Unibertsitatea \\ aferran@deusto.es
}

\section{Cinta Guinot Viciano}

Gizarte Laneko eta Soziologiako Departamentua, Deustuko Unibertsitatea

\begin{abstract}
Aporofobia pertsona pobreei edo babesgabetasun egoeran daudenei diegun beldurra eta errefusa azaltzeko erabiltzen da. Azken urte honetan eta 2017 ko abenduan RAEk bere hiztegian sartu zuenetik, hainbat idatzietan azaldu den hitza da. Kontzeptua eta mugatu nahi duen errealitatea, ordea, ez da batere berria: pobretuenenganako aurreiritzi eta estereotipoak bereizi nahi ditu, beste giza taldeenganakoetatik. Artikulu honek bi atal nagusi ditu: lehenean, hitzarekin jolasean aritu gara, zehaztu nahi duen kontzeptuarekin eztabaidan: zer da aporofobia, zergatik ematen da gurean, ze ondorio ditu guregan eta pobretuenengan. Horretarako, ezinbestekoa da pobrea eta pobretuaren arteko muga lantzea eta egoera horien guztien erruak edo ardurak norenak diren aztertzea. Bigarren atalean, berriz, arbuiatze-jarrera horien aurka ekiteko hezkuntzak duen erronka azaldu nahi dugu. Aurreiritzien eta estereotipoen eraikuntzan pentsamenduen, emozioen eta jokabideen elkar eraginak zerikusia duenez, horiei aurre egiterakoan, hiru ezagutza mota landu beharko ditugu: jakintza, ekintza eta izatea. Atal honetan, aporofobiaren aurka ekiteko Deustuko Unibertsitateko Gizarte Laneko ikasketetan egiten dugun esperientzia kontatuko dugu, ikasleen ahotsak entzunez.
\end{abstract}

\section{GAKO-HITZAK:}

Aporofobia, aurreiritziak, estereotipoak, gizarte lana, hezkuntza.
El vocablo aporofobia se utiliza para definir la fobia a las personas pobres o desfavorecidas. Desde que la RAE lo incorporó a su diccionario, en diciembre de 2017, ha sido utilizado en diferentes artículos. Sin embargo, el concepto que subyace y la realidad que pretende describir no son, en ningún caso, novedosas: quiere diferenciar los estereotipos y prejuicios hacia las personas empobrecidas, de otros grupos sociales. El artículo que presentamos está dividido en dos partes: en la primera hemos jugado con el vocablo y hemos delimitado el concepto que quiere definir: qué es la aporofobia, cuáles son las razones que sustentan el miedo al pobre y qué consecuencias tiene en nosotros y en las personas empobrecidas. Para ello es fundamental abordar la fina línea que divide los conceptos de pobre y empobrecido; y abordar las "culpas" o responsabilidades de esas situaciones. En la segunda parte hemos querido plasmar el reto de la educación para ir en contra de las actitudes de rechazo. Si en la construcción de los estereotipos y prejuicios se ponen en juego nuestros pensamientos, emociones y comportamientos, para luchar contra ellos tendremos que activar los tres tipos de conocimientos: conceptuales, emocionales y actitudinales. En esta segunda parte presentamos una experiencia de abordaje de la aporofobia vinculada al grado de Trabajo Social de la Universidad de Deusto, a partir de las voces de las y los estudiantes que la han realizado.

\section{Palabras clave:}

Aporofobia, prejuicios, estereotipos, trabajo social, educación. 


\section{Hitzarekin jolasean: izena duena izana du}

Aporofobia hitza, 2017ko abenduan, hitzen kategoria nagusiko ligan sartu zuten. Orduan, urtetan hainbat pertsona eta erakundek bere sarreraren aldeko eskaerak egin eta gero, Espainierako Errege Akademiaren (RAEren) hiztegian jaso zen: "pertsona pobreei edo egoera okerrenean daudenei diegun beldurra"-ren esanahiarekin. Urte horretan bertan, Fundación del Español Urgente (Fundéu BBVA) entitateak 2017ko hitz izendatu zuen.

Aporofobia, bi hitz greko lotzen dituen hitz berria dugu: á-poros eta fóbeo. Lehenengo hitzaren esanahia da: pobrea, irteerarik gabea, baliabide urrikoa. Bigarren hitzaren esanahia, berriz, beldurra, ikara edo errefusa da. Beraz, aporofobia norbanakoan sortzen den sentimendutzat har genezake, hau da, pobrezia egoeran dauden edo eta baliabide nahiz bitartekorik ez duten pertsonek sortarazten diguten beldurra, errefusa edo arbuioa.

Jarrera aporofoboa eta dituen ondorioak lantzeak, eta bazterkeria egoera eta pobrezia jasaten duten pertsonenganako arbuiatze-jarrera honetan eragiten duten elementuen inguruko gogoeta egiteak, aurrez, hiru elementu hauen inguruko hausnarketa egitea dakar, alegia: aurreiritziak, estereotipoak eta diskriminazioa. Marcelo Andradek (2008), Giza Zientzietan doktore brasildarrak, adierazten duen gisara hiru kontzeptu horiek munduarekin dugun harremanetarako modua egituratzen dute, hala nola, besteekin eraikitzen ditugun harreman motak ere. Ditugun aurreiritzi eta estereotipoetan oinarriturik, norberarenak ez diren beste giza taldeenganako errefusa eta arbuiatze-jarrerak eduki ditzakegu.

Beraz, autoreari jarraikiz, aporofobia kontzeptua landu baino lehen ezinbestekoa da etnozentrizmoaren kontzeptura gerturatzea. Andraderen esanetan (2008), etnozentrismoak "gure" eta "besteak" arteko distantzia azpimarratzen du. Hori horrela izanik, ezberdintasuna (hots, bestea) ez da altxor gisara ikusten, ez da aberasgarritzat hartzen: ezberdintasunak beldurra sortarazten digu. Beldur honetatik abiatuz, eta aporofobian gertatzen den erara, ezberdinarenganako gorrotoa edo eta errefusaren sentimenduak betetzen gaitu: pertsona deseroso, gogaikarri edo azpikotzat ditugunenganako gorrotoa edo errefusa.

Andradek (2008) adierazten duena kontuan izanik, pentsamendu etnozentrikoak hierarkia terminotan kokatzen ditu ezberdintasunak: hori horrela izanik, gizaki batzuk besteak baino hobeagoak edo goi mailakoak kokatzen ditu, eta, besteak, berriz, okerragoak eta menpekoak. Hierarkia honek, gizarte egituraren osaketan eragiten du eta ezberdintasunak eta klasifikazioak ezartzen ditu, gizarte talde ezberdinen artean.

Munduaren ikuskera etnozentriko honen eraikuntzan hiru dimentsio edo esfera sartzen dira jokoan, hala nola: gure pentsamenduak, gure emozioak eta gure jokabideak. Lehenengoari erreparatuz gero, pentsamenduen dimentsioan, hain zuzen ere, etnozentrismoak gizakian honako ideia hau sorrarazten du: ezberdintasuna negatibotzat hartzearen ideia, onargarria ez den zerbait. Noski, ideia hauek guztiak aurreiritziak sortzea dakarte. Bigarrenik, emozioen dimentsioan, etnozentrismoak ezberdina denarenganako etsaitasunezko sentimenduak sorrarazten ditu eta sentimendu honek estereotipoak eraikitzea dakar, ezberdinarenganako beldurrean eta errefusean oinarritutako estereotipoak, hain zuzen ere. Hirugarrenez, ekintzaren dimentsioan kokatzen ditugu giza jokabideak eta horiek jarrera diskriminatzaileak edukitzera bultzatzen gaitu, ezberdintzat hartzen ditugun gizakienganako, hau da, marjinatzen eta baztertzen ditugun horienganako.

Hiru dimentsio hauek (esaterako: osagai arrazionalak, afektiboak eta jokabidekoak) jakin badakigu elkarren artean era sinergikoan lotzen direla, eta hiruak aporofobiaren sortzaile bilakatzen direla.

Aporofobia, beraz, aurreiritzi guztiak bezala, presaka egindako orokortasunak sortzen duen distortsioa da; hau da, estereotipo bat. Eta aurreiritzi oro bezala, faltsua eta arbitrarioa da, baina, tamalez, jokabide eta jarrera diskriminatzaileak sortzeko kapaza.

Adela Cortinak, filosofo eta etikako katedradunak, 1995. urtean erabili zuen lehen aldiz aporofobia hitza. Garai horretan, hitz espezifikoa jartzeko beharra zegoela ulertzen zuen Cortinak; arrazismoa eta xenofobia kontzeptuak zehazte eta mugatze aldera, pobreenganako errefusa, ezinikusia eta beldurra biltzen zuen gertaera soziala izendatzeko. 2017. urtean, berriz, liburu bat argitaratu zuen eta gaia sakonki landu: Aporofobia, pobrearenganako errefusa: demokraziarentzako desafioa izenburua du, hain zuzen ere. Urte hauetan guztietan (bi hamarkada oso), Cortinak lan eskerga egin du errealitate hau azaleratzeko asmoz: hitza definitu, errealitatea mugatu eta ondorio etikoak aztertu ditu, hainbat artikulu eta hitzalditan.

Euskaraz badugu esaera zaharra: "izena duenak izana du”. Horrek ez du esan nahi izenik ez duena existitzen ez denik, baina bai, gertaera jakin hori zehaztasun handiagoz eta era egokiagoz aztertzeko, lehen urratsa hori izan beharko lukeela; alegia, egoera jakin bati izena jartzea egoera aztertzeko lehen pausoa da. Cortinaren hitzetan (2017: 24):

Izena jartzea premiazkoa da pobrearenganako, babesgabearenganako errefusari, jarrera horrek indar handia duelako gizarte bizitzan; are handiago du, hain zuzen ere, anonimatutik ekiten diolako. Halaber, ukatu ezin den errealitate honek antzematen den existentziarik ez duenez, ezin da desaktibatu.

Gizarte Lanaren diziplina abiapuntu izanik, errealitatea antzemateko eta gizarte eraldaketa sortzeko, gertatzen den horri izena jartzea 
ezinbestekoa dela ulertzen dugu; hots, gizarte gertaerak eta gizakien jokabideak izendatzea. Hau da bidea inplizitua dena esplizitu egiteko, eta, behin errealitatea ikuskatzen denean eta errealitate horren funtzionamenduak sortzen duen sarea ulertzen denean, orduan bai, eman daitezke aldaketarako alternatibak sortzeko aukerak.

Ildo horretan jarraituaz, Andraderen ustetan (2008) neologismoak bi arrazoiengatik sortzen dira: errealitate berria izendatzeko edo eta hain berria ez den errealitatea edo gizarte gertaera jakin bat, ordura arte izendatu ez dena, berrizendatzeko. Aporofobiaren kasuan, gure uste apalean garbia da, bigarren egoera hori da nabarmendu behar dugun arrazoia: pobrezia eta bazterkeria egoerak jasaten dituzten pertsonenganako diskriminazioa eta errefusa ez baita soziologikoki egoera batere berria. Hala nola, berritzat har dezakeguna da diskriminazioa sortzeko eragiten duten ñabardurak aztertu eta ulertu ahal izatea.

Finean, hitz berri honen esanahia zehaztu ondoren eta hitzak adierazten duen gizarte errealitatea izendatzeko garrantziaz jabetu ondoren, nahitaez, hurrengo pausua eman beharra dago eta sakoneko galderei erantzuteko saiakerari heldu behar diogu: nondik dator pobrearenganako fobia edo beldurra? Nondik, babesgabearenganako errefusa? Nola eta zergatik errotzen da guregan aporofobia?

\section{Kontzeptuarekin eztabaidan: mugetatik haratago}

André Glucksmannek, frantziar filosofo eta saio-idazleak, honako tesi hau mantentzen du Gorrotoaren diskurtsoa liburuan (Glucksmann, 2005): gorrotoa, berez, existitzen da, bai maila mikroskopikoan (hau da, norbanakoaren mailan), bai eta gizatalde erraldoietan ere. Tesi honen harira, pobrearenganako fobia eta errefusa, jendeak duen gorrotoaren isla izango litzake. Besterik gabe.

Autoreak, esandako liburuan, hainbat gorroto tipifikatzen eta aztertzen ditu, besteak beste, emakumearenganako gorrotoa. Bere esanetan, historian izan den gorrotorik zaharrena eta unibertsalena (gure esanetan, izaten jarraitzen duen gorrotorik zaharrena). Gorroto honen sorrera Homeroren Ilíadan kokatzen du, hain zuzen ere, Helenaren pertsonaian eta bere bizipenetan; Helena da gaitz guztien sorburua. Baina, zer da, mendez mende eta lurraldez lurralde, emakumearenganako gorrotoa iraunarazten duen hori? Autoreak garbi ematen du bere erantzuna: emakumearen ahulezia, denona dugun ahulezia, hain juxtu ere. Bere zaurgarritasuna, gizasemeek bertatik ihes ezin dezaketen zaurgarritasun bera. Bere hitzetan: "emakumearenganako gorrotoak larritasuna, dezepzioa ezkutatzen du; azken finean, norberarenganako gorrotoa. Ispiluak bueltatzen duen isla ez onartzeko, ispilua puskatu egiten da" (Glucksmann, 2005: 229).
Cortinaren (2017) ustetan, pobrearenganako errefusak, beste gorroto edo beldurrek ez bezala, badu berezkotasuna. Besteak beste, nahigabeko pobrezia (norbanakoak, libreki, hautatu ez duen pobrezia, alegia) ez da pertsonen identitatearen ezaugarria, ezta erabakitzen den egoera ere. Aitzitik, Glucksmannek jartzen dituen adibideetan, hau da bereizi gabeko gorrotoaren jomuga diren gizataldeetan, identitatearen zantzua nabarmena da: estatubatuarrak, juduak, emakumeak...

Ildo honetatik jarraituz, José Expósito Marín soziologoarekin bat gatoz bi kontzeptu hauen arteko bereizketa egitearen garrantzia aipatzen duenean: pobrea eta pobretua (Expósito Marín, 2016). Bi kontzeptuak errealitate berdin bati buruzkoak badira ere, bien artean ezberdintasun mehea bezain garrantzitsua dagoela dio: pobrea, izenondoa da; identitateari atxikitako ezaugarria, norberarena, izateari lotua. Pobretua berriz, pobrezian egoteko ezaugarria da, egiturazko egoera jakin baten ondorioz gertatutakoa, barruko nahiz kanpoko arrazoiak bultzatuta jazotakoa. Egoteari lotua, beraz.

Expósito Marínentzako (2016) aporofobia taldeen arteko harreman gisara ulertu beharra dago. Esandako harreman hori aurreiritzi batean oinarritua dago, eta, pobreziaren ideia ardatz harturik, gizartean giza talde edo giza kategoria berri bat sortzen da, non beste taldeek gorrotagarritzat hartzen duten. Era honetan, ikuspuntu hau ontzat harturik, pertsona aporofoboa ez da gai pobretua dagoen gizakiaren errealitatea eraikitzen duten hainbat aurpegiak ikusi eta aztertzeko. Horrela, pertsona horrekiko sortzen den iritzia era erredukzionistan sortua da, pobretuenganako aurreiritzian oinarritua. Beraz (aurreiritzi guztiekin gertatzen den bezala), ikuspegi mugatu, erratu eta erredukzionista horretan kokatzen ez den edozer alde batera utzia da.

Eta pobrezia pertsonaren identitatearen ezaugarria ez bada (egoera bai, baina ez izaera), non errotzen da beraienganako beldurra, ikara? Eta errefusa?

Orain, testuaren une honetan, bi multzo hauen arteko bereizketa egitea garrantzitsua dela iruditzen zaigu. Ez baita berdina beldurra eta errefusa. Beldurrak errefusa ekar lezake, bai. Baina errefusak ez du zertan beldurrean oinarritua egon. Nola ulertu, bestela, gure familietan dugun pobrearenganako lotsa eta ezkutaketa? Ez da beraienganako beldurrean sostengatzen, gertuko taldearen, auzokideen edo gizarte zabalaren epaian edo guri sortzen zaigun lotsan baizik.

Aporofobiaren eta arrazakeriaren sorrera biologikoaren aldeko tesiak azaldu eta gero, Cortinak (2017) aipatzen du pobrea emateko ezer ez duen hori dela. Tesi horiek sostengatzen dira gizakiaren sorrera eta bere biziraupenaren oinarrietan: hau da, gizakiak, bere biziraupenerako, gertukoen solidaritatea eta kanpotarrenganako defentsa ezin bestekoak zituen. Eta horrela, beti ere biziraupenaren 
helburuarekin, lankidetza eta elkar trukea garatzen joan ziren, noski, eskaintzeko zerbait zuten horiekin guztiekin.

Hori horrela izanik, hartu-emanean eraiki den zibilizazioan, emateko ezer ez duen hori, pobrea, alegia, baztertua da: "eskaintzekorik ez duelako, edo hori dirudielako" (Cortina, 2017: 21); "pobrea da, hartu eta emanaren jokoan oinarritua dagoen munduan, zerbait bueltatzeko aukeratik kanpo geratzen dena” (Cortina, 2017: 80).

Emilio Martínez Navarro filosofia moraleko irakasleak ere (2002) ideia honen inguruan aritu da. Bere ustetan, aporofobia ulertzeko gakoetako bat hauxe da: gizarte bizitzan badaude itunak egiteko boterea duten pertsonak, eta beste hainbatek, berriz, ez dute botere hori. Beste era batera esanda: badira boteretsuei interesatzen zaien zerbait duten pertsonak; beste batzuek, ordea, ez dute ezer interesgarria denik boterea dutenentzako. Beraz, gizarte merkantilista honetan, hitzarmenean eta itunean oinarritua dagoena, ezer eskaintzeko ez duen gizakia baliogabetzat hartzen da: beharrezkoa ez dena, premiarik gabea, eta, horrenbestez, baztertuak dira, alboratuak, alderatuak. Horrexegatik, pertsona pobretuen errealitatea eta egoera ez da, inolaz ere ez, interesgarria, gizarte sektore handi batentzako.

Estigmatizazio hau oinarri harturik, hau da, pertsona pobretuak gizarteari eskaintzeko ezer ez dutenaren usteak, gizarte bazterkeria legitimatzen du eta gizatalde bat baztertzeko estrategiak gauzatzen dira, hain zuzen ere, pobreen kategorian kokatzen dugun gizataldearenganako bazterketa estrategiak. Maria Cristina Bayón soziologo mexikarrak azaltzen duenari jarraikiz (Bayón, 2013), pobreen estigmatizazio eta kriminalizazioak ezberdintasunaren legitimazioa bultzatzen du, eta sektore aberatsenen eta boteretsuen pribilegioak indartzen ditu.

Pertsona pobretuak eman eta jasotzeko jokoan parte hartzerik ez dutela kontsideratzeak, eta, beraz, gizarte bazterketa eremuan, kanpoaldean kokatzeak, Zigmund Bauman soziologo, filosofo eta saio-idazle poloniarrak jaso du bere idatzietan. Baumanek (2005) argi eta garbi azaldu du ideia hau errefusaren metafora gordina erabiliaz. Bere esanetan, gizartearen zati bat pobrezia egoeran bizi da, gure gizarte funtzionamenduaren egituragatik: ezarrita dagoen gizarte ordena da, herritarren zati bat, bere gogoz kontra, gizarte parte hartzearen esparrutik kanpo uzten edo kokatzen dena. Era honetan, kontsumo-gizarteak bizitza modu batzuk zokoratu egiten ditu; hain juxtu, "soberakintzat" hartzen dituen pertsonen bizitza moduak.

Soberakintzat hartutako pertsona horiek guztiak, baztertu dituen gizarteak berak kokatzen ditu errefusa birrintzeko, deuseztatzeko lekuetan. Baumanek dio, hirietan sortzen diren leku horiek hiri-ghettoak edo hiperghettoak direla. Ghetto tradizionalak diskriminazioaren aurrean babes funtzioak betetzen zituzten; hauek, ostera, “zabortegi sozialak" dira: gizarte segregazio gune bihurtzen dira (edo bihurtzen ditugu).

Jokaera hau, alegia, hiri-ghettoak sortzearen jokaera, instituzionalizatutako aporofobia kontsidera daiteke, Expósito Marínek (2016) azaltzen duen ideiari helduaz. Bere hitzetan, instituzionalizatutako aporofobia gizarte-praktika egiturazkoak eta sinbolikoak sortutako sarea da, non pobrezian bizi den biztanleriarenganako praktika diskriminatzaileak sortzen eta birsortzen doaz, amaierarik gabeko kate luzea osatuz.

Jokaera aporofoboak nola sortzen, oinarritzen eta indartzen diren aztertzen ari garen honetan, Cortinaren eta Martínez Navarrok esandakoak Richard Sennett soziologo estatubatuarraren hainbat ideia ekartzen dizkigute gogora. Bere liburuetan, pobrearenganako errefusa lotzen du gure gizartearen nortasun kulturalaren muinean dagoen independentziaren balorearekin. Gure gizartean gailendu den balorea balitz bezala, gizakiaren helburu nagusia honako hau bilakatzen dela dio: besteenganako inolako loturarik gabe garatzea, burujabea izatea.

1998. urtean, kapitalismo berriaren paradigmaren atzaparretan lanean aritzeak, norbanakoaren izaeran zituen ondorioak aztertzeko asmoz argitaratu zuen liburuan (Sennett, 1998), zioen egungo gizartean besteenganako dependentzia (bai lan esparruan, bai gizarte politikaren esparruan) ezaugarri lotsagarritzat hartzen dela. Ideia hau abiapuntu izanik, gizarte kapitalista honetan, Estatuaren babesean daudenak benetako babes beharra duten pertsonak kontsideratu beharrean, parasito sozialtzat (Sennett, 1998: 26) hartzen dira, erabat mespretxatuz. Gainera, ez da esparru publikoan mantentzen esparru pribatuan onartzen den hori, alegia; gizakia egoki garatzeko nahitaez behar dituela besteenganako loturak. Edo, beste era batera esanaz, independenteak izan beharrean elkarmendekoak garen ustea.

Ideia hau beste idatzietan jasoa du Sennettek. Honela, Errespetua izenburupean idatzitako liburuan adierazten duenez dependentzia lotsagarri agertzen da eremu publikoan eta besteenganako dependentzia, ahuleziatzat hartzen da: "premia egoera saihesten duen eta autosufizientzian indarra jartzen duen giza zorroztasunak, besteen begietan errespetua sortzen du, eta norberarenganako errespetua ere indartzen du" (Sennett, 2003: 109).

Are gehiago, Sennettek dio menpekotasuna eta lotsa lotzeak kultura jakin baten ezaugarriak besterik ez direla (Sennett, 2003: 121). Beraz, besteenganako menpekotasuna daukagula edo onartzen dugula adierazten dugunean, egoera lotsagarritzat hartzeak (hau da, bi kontzeptu hauek lotzeak), ez da lotura unibertsala; ez da kultura guztietan gertatzen.

Egiaz, egungo mendebaldeko gizartean, gizarte aurreratuan, garapenaren kultura ezarri zaigu: 
hainbat eta hainbatetan entzun eta irakurri dugun “amerikar ametsaren" adierazlea, porrota ezkutatzen den kultura; merezimenduan oinarritua, hots, meritokraziaren gobernua.

Luze hitz egin dute autoreek lanaren etikaren gaiaren bueltan, merezimenduaren kontzeptuaz: lan eta lan egin eta lortuko duzu merezi duzuna. Egun ere, erretiratutako pertsonen manifestazioetan, hauxe da leloa: "guk egin dugu lana, guk egin ditugu gure ekarpenak Gizarte Segurantzaren zorrora, merezi dugu, beraz, Estatuaren erantzuna eta babesa”.

Eta kultura honetan, zer da, ba, orduan, pobrezia? Zein, pobrea? Ziurrenik ez da soilik elkar banatzeko ezer ez duen hori. Ziurrenik, pobrea da, erabaki desegokiak hartu ondoren, nahikoa lan egin ez duen hori; nahikoa saiatu ez den hori.

Baina, ezaugarri horiek guztiek, alegia; elkar banatzeko ezer ez duena, erabaki desegokiak hartu dituena, nahikoa saiatu ez dena, protagonista bakarra dute: norbanakoa, pertsona. Ez dira gizarte egituraren ezaugarriak ezta gizarte antolaketaren ondorioak ere. Beraz, erraza da erruak banatzea: pobrea da bere egoeraren arduradun bakarra, eta horrela izanik, ez dugu kontuan eduki behar, baztertu egingo dugu, arbuiatu egingo dugu.

Argudio hauek guztiak eta horien elkarren arteko eraginak aporofobiaren logika gailentzera eramaten duen sare ilun eta ezkutua sortzen doaz. Isil edo ozen. Baina, dudarik gabe, irmo.

Hori horrela izanik, pobrezia gizarte eraikuntza bezala aztertzearen garrantzia ezin dugu nabarmentzeaz utzi. Bayónek (2013) azaldu duenari jarraituz, egiturazko atal honi begiratzeak emango digu aukera pobreziaren naturaltasuna aditzera ematen duten mekanismoak desegin eta eraisteko. Hau guztia ezinbesteko zaigu, pobrezia pairatzen duen norbanakoa gure azterketen erdigunetik kentzeko, bere dimentsio indibidualean eta errudunean, pobrezia pairatzeak norbanakoak hartu duen aukera balitz bezala. Hala nola, azterketen erdigunean gizarte egiturak, politika eta erakundeak kokatzen baditugu, pobreaz baino, pobretuaz hitz egingo dugu; norbanakoak baino, egiturak aztertuko ditugu; erruak baino ardurak banatuko ditugu.

\section{Erruak edo ardurak?}

Hauxe da, besteak beste, Andradek (2008) azaldu nahi diguna pertsona pobretuak enbarazu egiten digutela adierazten duenean: pobretuen presentzia soilak traba egiten digu, gogaitzen gaitu, haien egoteak dugun ardura gogorarazten digulako, ahaztu nahiko genukeen ardura. Autoreak dio, aporofobian “arduren jokoa" jartzen dela abian eta denek jolasten dugun jokoa dela. Beste era batera esanda, Andraden ustetan, aporofobiak gogora ekartzen du, hein batean, ardura sozial eta kolektiboa direla bai gizarte bazterkeria, babesgabetasuna edo eta zaurgarritasun egoerak; kondizio oparoan bizi garenok ere egoera horren ardura badugula.

Era honetan, pobreziaren existentzia bera interpelatzen gaitu, eta, herritar garen heinean, gizaki orokin dugun elkarrekiko ardura gogorarazten digu. Pobreziaren existentziak gizartearen porrota morala nabarmentzen du. Beraz, eta porrot honen aurrean defentsa-mekanismo gisa, hainbatek duten erru eta ezinegonaren sentimenduak bultzatuaz, arbuiatzen dituzte pobrezia egoeran dauden pertsonak.

Ardura hori baztertzen dugunean, gure gain hartzen ez dugunean, orduan pertsona pobretuari eragozten diogu bizi duen miseria egoeraren karga. Hauxe da guregan logika aporofobikoa gailentzen den unea, gure buruari, isil edo ozenki, hauxe esaten diogunean: pobrezia eta bazterkeria egoerak bizitzen dituzten pertsonak dira egoera horien arduradun lehenak eta nagusiak. Azken finean, aporofobia, pobreenganako errefus sentimendu gisa, gure arduragabekeriarengatik ere sortzen da eta.

Kontakizun honetan guztian, adierazi dugu aporofobiak ez duela aurpegi bakarra eta nabarmena. Aldiz, era mehe baina irmoki sortzen eta errotzen doan sentimendu eta aurreiritzia da. Aporofobia ez da elkarreraginean soilik sortzen, ezta norbanakoaren jokaera arbuiagarrietan ere. Besteak beste, gizarte egiturak sortutako aurreiritzi eta estereotipoetan iruten den sentimendua ere badela ikusi dugu. Gizarte egitura berak indartzen du pobrezia eta bazterkeria egoerak bizi dituen pertsonarenganako diskriminazioa; gizarte egitura da pertsona horiek nortzuk diren eta nolakoak direnaren inguruan etiketak eta klixeak egozten dituena; pobreen kategorian kokatzen dituena, norbanakoak egindako aukera pertsonala balitz bezala.

\section{Zaharrak berri: errealitate gordin bati izena jarriaz}

Kontzeptua mugatzeak eta definitzeak garrantzia handia du, nola ez: izanari izena ematen baitio eta izena duena izana baduelako. Izena izateak pobretuenganako arbuiatze-jarrerak ikuskatzeko eta azaleratzeko bidea ematen dio eta beste jarrera arbuiagarri eta xenofoboen arteko bereizketa egiteko bidea ere azaleratzen du. Baina, argi dugu: jarrera hau, pobretuenganako errefusa, ez da berria, zaharrak berri ditugula gurean. Berria dena, hori bai, eta ez da gutxi, egoeraren kontzeptualizazioa da. Edo zehazkiago esanda: berria dena kontzeptuak hartu duen fama mediatikoa da; gizartearen (edo hobeto, gizartearen zati baten) fokua bertara zuzendu da eta hitzen kategoria nagusiko ligara iristeko aukera izan du. Ez da gutxi, egia da, mementoko fama honek bidea eman baitu diskriminazio hori sortzen duten faktoreen inguruko gogoeta egiteko eta, ondorioz, dinamika aporofobikoak ahultzeko alternatibak bilatzeko aukera piztu du gurean. 
Gizarte Lanean, beste gizarte zientzietan bezala, askotan, itsasoan euria egitea behar izaten dugu, gordeta, ezkutuan eta enkistatuak dauden errealitateak azaltzeko eta azaleratzeko. Are gehiago, errealitate hauek pertsonen duintasunaren errespetuari edo eta bere eskubideen aitorpenari muzin egiten diotenean. Euria beharrezkoa dugu gogoeta hazteko: gure jarduera aporofobikoak nola sortzen diren aztertzeko, sorreran eragiten duten egiturazko kausak zeintzuk diren ulertzeko eta pobretuenganako arbuiatze-jarrerak ez bultzatzeko estrategiak bilatzeko.

\section{Aporofobia hezkuntzaren esparruan landuz: erronka eta jarrerak aldatzeko aukera}

Orain arte esan dugunaren haria jarraituz, aporofobia ez da gauza berria gurean. Gizarte Laneko graduko irakasle garen honetan eta Gizarte Laneko ikasleen rol profesionala egituratzen laguntzaile garen honetan, Fred Kofman idazle argentinarrari jarraikiz (Kofman, 2001), garapen profesionala hiru dimentsioz osatutako prozesua dela ulertzen dugu: lehena, kontzeptuak ulertzeko gaitasunari loturiko dimentsio kontzeptuala; bigarrena, abilezia profesionalei loturiko dimentsio teknikoa; eta hirugarrena, norbere burua ezagutzeko eta ezaguera hori besteekin era egokian erlazionatzen erabiltzeko gaitasunari loturiko giza dimentsioa.

Deustuko Unibertsitatean eskaintzen dugun Gizarte Laneko graduko irakasgai batean, aurreiritzien eta estereotipoen inguruko gaia lantzen dugu, aspaldian. Halaber, jarrera diskriminatzaileengan horiek duten eragina ere aztertzen dugu. Gai honetan, esangura berezia du aporofobiaren ezagutza, eta, ikuspegi kontzeptualetik haratago, aurrez aipatu ditugun hiru dimentsioak lantzen ditugu: ezagutzea (dimentsio kontzeptuala), egitea (dimentsio teknikoa) eta izatea (giza dimentsioa). Era honetan, konpetentzien garapenari loturiko hiru ezagutza maila jorratzen dira: jakintza, ekintza eta izatea:

- Jakintza: atal kognitiboa da, dimentsio kontzeptuala, ikasleak bere ikaskuntzan lortzen duen ezagutza kontzeptualari lotua dago.

- Ekintza: aplikazioaren atala da, egiten jakiteari lotutakoa, behin ikasleak ezagutza kontzeptuala duenean aplikatzen lagunduko dion ezagutza da.

- Izatea: emozioen atala da, giza dimentsioari lotutakoa eta ikaslearen garapen pertsonala landuko duen ezagutza da.

Aporofobiaren inguruko hausnarketan hiru dimentsio edo ezagutza mota hauek esangura berezia dute. Gogoan izan, aurrez aipatu dugun Andraderen hitzetan, munduaren ikuskera etnozentriko honen eraikuntzan hiru dimentsio edo esfera sartzen direla jokoan, hala nola: pentsamenduak, emozioak eta jokabideak. Eta hiru dimentsio hauen elkar eraginak bultzatzen duela aporofobiaren sentimendua.
Beraz, aporofobiaren aurka egin nahiko badugu, hiru dimentsioetan eragin beharko dugu: kontzeptuak ikuspegi kritiko batetik aztertuz eta arrazoiak deuseztatuz; jarrerak ikuskatuz eta aldatuz; eta emozioak azaleratuz eta ulertuz.

- Jakintzaren atala garatzeko, ikasleek hainbat testu ezagutzen eta ulertzen dituzte eta testuetan irakurritakoari helduz, horien inguruko solasaldia edo eztabaida egiten dute.

- Ekintzaren atala garatzeko, ikasleek esku artean duten kasuaren ebazpenean jarrera aporofobikoak ikusten eta horiei aurre egiteko estrategia eraginkorrak plazaratzen saiatzen dira.

- Emozioen atala garatzeko, berriz, ikasleek norbere burua aztertu eta norbere jarrera aporofobikoak identifikatzeko introspekzio lana egiten dute.

Ikusi dezagun, orain, zeintzuk izan diren irakasgai honetan ikasleek lortutako ikaskuntza esanguratsuak, beti ere, haien ahotsei erreparatuz. Hau guztia lantzen den irakasgaia, Esku Hartzeko Prozesu eta Teknikak deiturikoa da. Gure graduan, irakasgai honek Gizarte Laneko graduko ikaslearen profilari honako ekarpena egiten dio: norbanako, familiako eta taldeko esku-hartze profesionalerako metodo eta teknika zehatzak erabiltzeko gaitasun, abilezi, konpetentzi eta jarreren garapen eta lorpena. Gainera, testuinguru sozial, ekonomiko eta kultural jakin batean bizi diren pertsona nahiz taldeak bizi dituzten egoera arazotsuenganako gerturatzea ahalbidetzen du, nola ez, gogoetarako jarrera batetatik abiatuz.

Irakasgai honek esku-hartzerako alternatibak proposatu eta sortzeko aukera ematen dio ikasleari. Beti ere, norbanako, familiako nahiz taldeko arazo eta egoera psikosozialei irtenbidea bilatzeko asmoz.

Horretarako, ikaslea bere jarrerei buruz gogoeta egiteko prestatzen da eta gizarte langile moduan izango duen berezko estiloaren eraketa eta finkatzea bultzatzen ditu; honela, arazoen aurrean erantzun eta irtenbide egokiak, era arduratsuan, emateko gaitasunak landuz.

Ikasleak, laguntza harremaneko metodologia eta teknikak ikasi eta bereganatuko ditu. Beraz, ezinbestekoa da harreman profesionalean agertzen diren jarrerak eta aurreiritziak aztertzea, gizartean gailentzen direnak, eta, nola ez, norberak dituenak. Hemen kokatzen dugu aporofobiari buruzko gaia, hain zuzen ere, pobretuenganako aurreiritzi eta estereotipoak aztertzeko eta gainditzeko gaia. Ikasleak gogoeta lan idatzia egin behar du aurrez aipaturiko hiru dimentsioak edo eta ezagutza motak landuaz: jakintza, ekintza eta izatea. 


\section{Ikasleen ondorioak ${ }^{1}$}

Ikus dezagun, bada, irakasgai honetan izan ditugun ikasleen ondorioak, azaldutako hiru dimentsioetan banatuak.

\subsection{Jakintzaren atalean hauek dira ideia eta ezagutza aipagarrienak}

Batetik esan, ikasleek gai direla aporofobia kontzeptua definitzeko eta egoera praktiko bati lotzeko; hau da, errealitatean ikuskatzeko eta identifikatzeko. Dena den, kontzeptua berria gertatzen zaie, hitza bera eta hitzaren esanahia ere, baina ez deskribatzen duen errealitatea. Hau adierazten dute Gizarte Laneko graduan zehar hainbat irakasgai landu dituztelako gizarte bazterkeriari eta pobreziari lotutakoak. Zehaztu beharra dugu, estereotipoak eta aurreiritziak lantzen dugun irakasgai hau, graduko hirugarren mailako bigarren seihilekoan kokatua dagoela: ordurako, ikasleek titulazioa lortzeko egin behar duten ibilbidearen hiru laurdenak egin dituzte eta ikuspegi profesionala emateko gai dira (gazte hauek 21 urte inguru dituzte). Bestalde, ezin bestekoa gertatzen da estereotipo eta aurreiritzien gogoeta hau egitea laugarren mailako praktiketara joan aurretik, bertan bizituko dituztenak hobeto ulertu eta kokatze aldera.

Hau horrela izanik, ikasleek aporofobia terminoarenganako lortzen duten ezagutza, pobrezia eta bazterkeria egoerak sortzen dituzten kausenganako ezjakintasunaren aurrean jartzen die, ispilua izango balitz bezala. Horrela, arbuiatzejarreren arrazoi eta zioenganako sakontzea ahalbidetzen die, eta, kontzientzia hartze hau, errealitatea ikuskatzeko behar beharrezkoa den lehen pausoa da.

Ikasleek garrantzia ematen diete ezagutzaren lehen atal honi:

Bestalde, lan honek eta orokorrean gai honek asko erakutsi dit, batetik, gaia nire gustukoa delako eta bestetik, gaiaren inguruan asko ez dakitelako. Estereotipo eta aurreiritziaren arteko ezberdintasuna jakiteak balio izan dit biek indibidualki ulertzeko eta bakoitzaren definizio argi bat edukitzea eta ulertzea positiboa iruditzen zait; niretzat behintzat baliagarria izan da.

Honetaz gain, orain kontzienteago naiz aporofobiaren errealitateaz eta horrek gure gizartean duen pisuaz. Ezagutzen ditudan kasu pertsonalei zentzua ematen egon naiz, errealitate honekin loturik, eta pobreen irudiak gizarteari

${ }^{1}$ Atal honetan jaso ditugun aipuak, 2017-2018 ikasturtean Deustuko Unibertsitateko Donostiako campuseko Gizarte Laneko 3. mailako ikasleen lanetatik ateratakoak dira. Guztira 60 ikasle, bi taldetan banatuak, eskolaren hizkuntzaren arabera: euskarazko taldean nahiz gaztelaniazko taldean. sortzen dion beldurra argiago ikusi dut, eta eskuzabaltasunaren gabezia handiaz ohartu naiz.

Aporofobiaren gaia landu dugun lehengo aldia izan da eta oso garrantzitsua den errealitate bat da gure profesioan, izan ere, aporofobia sufritzen duten milaka pertsona ezagutuko ditugu gure profesioan.

Bistan denez, aporofobiaren kontzeptuaren ikasketak, pobretuenganako errefusa sortzen dituzten argudio eta arrazoien kontra egiteko lehen urratsa da eta aporofobia beste jarrera estereotipatuetatik bereizteko aukera ere: xenofobia edo arrazakeria bezalako jarrera diskriminatzaileaz, esate baterako.

\subsection{Ekintzaren atalean, berriz, hauxe da aipagarriena}

Ikasleek pauso bat haratago eman eta ikasitakoa esku artean duten kasu praktikoan ez ezik, beraien buruan ere ikusten saiatzen dira. Norbere buruaren azterketa egin eta, zailtasun bat edo beste gaindituz (nori gustatzen zaio bere ahuleziak plazaratzea?), norbere jarrera aporofoboak definitzen ahalegintzen dira. Nabarmena da hainbat ikaslek pauso hau emateko duen zailtasuna, ez baita erraza onartzea balorazio negatiboa eman zaien jarrerak ditugula, eta, gainera, lan akademiko batean plazaratzea:

Lan honekin eta gai honen jorrapenarekin ikasi dudan gauza garrantzitsuena nik ere estereotipo eta aurreiritziak ditudala izan da. Egia esan lan gogorra egin zait, eta asko kostatu zait honi buruz idaztea. Hasieran ez nintzen nire estereotipo edo aurreiritziak identifikatzeko gai, banituela uste nuen baina zein ziren ez nekien, orain ordea, pentsatu ondoren, identifikatzeko gai sentitu naiz.

Erronka, beraz, garbia da, eta ikasleek zintzotasunez onartzen dute eta aurrera eramaten dute: pobrezia egoeran bizi direnenganako norberak dituen arbuiatze-jarreren identifikazioa eta onarpena:

Gogoz kontra onartzen dudan arren, onartu beharra dut, aporofobia jarrera irrazionala dela iruditzen zaidan arren, irrazionala, immorala eta etika gutxikoa, askotan nik ere izan ditut hainbat pertsona baztertzeko jarrerak, zaurgarritasun egonera edo eta bazterketa egoeran dauden hainbat pertsonenganako arbuiatze-jarrerak.

Beraien aurretik pasa naiz, kasurik egin gabe, ikusi ere egin gabe, existituko ez balira bezala, ezin ikusiak balira bezala, eta haiek bizi dezaketen ikusezintasun sentsazio horretatik abiatuz, hori gutxiespen eta gaitzespen sentimendutzat har dezakete. Eta ez da horrela.

Ikasle askok gai dira onartzeko, beraiek ere, pobrezian bizi diren pertsonak baztertzen dituztela: ezagutu baino lehenago epaituz eta haiengana 
axolagabetasunez jokatuz. Irakasgai honetan egiten duten gogoeta honek ikasleari hainbat jokaerekin konektatzea ahalbidetzen dio: konfiantza eza, beldurra edo eta lotsa. Egunerokotasunean ematen diren jarrerak azaltzen dituzte, beldurrean oinarritutakoak, eta pobretuenganako kontaktua saihesteko erabiltzen direnak: sufrimenduarekiko urruntzea eta pobrezia ez ikustea:

Ditudan beharren inguruan hausnartzea eragin dit. Profesioaren barruan mila gauza ditudala oraindik ikasteke. Gainera, nire beharren eta kapazitate inguruan ere hausnartu dut. Baita, ditudan beldurren inguruan.

Aipatzekoa da, nahiz eta hauek errealitateari erantzun bat emateko izan, hauen inguruan hausnartzea oso garrantzitsua dela; epai okerrak ez egiteko, honek hainbat ondorio izan baititzake. Hau esanda, ez garela gaizki sentitu behar estereotipoak izateagatik azpimarratu nahiko nuke, baina honek ez du esan nahi ez ditugula jakin behar zeintzuk ditugun, izan ere, arriskutsua izan daiteke eta estereotipoekin erantzutea, bai alde pertsonalean, baita profesionalean ere.

la ikasle gehienek azpimarratzen dute, jokaera horiek aldatzeko ezinbestekoa dela errealitatera gerturatzea, orokortasunetik norbanakotasunera joatea. Pertsona partikularrekin, izen eta abizen duten horiekin, sortzen den lotura izango da jarrera aporofoboak saihesteko bide nagusia:

Aurre egin behar diegu, noski, eta horretarako onena gizabanako ezberdinekin egotea da, horiek ezagutzea horiekin partekatzea eta horrela, estereotipo asko ezabatuko ditugu.

Bi esperientzia hauek erakutsi didate estereotipoei aurre egiteko modu onena, horiengana gerturatzea eta hauek deuseztatzea dela. Mazarrak ere horrela adierazten du kultur pluralismoa sustatu beharra dagoela, desberdintasunak elkarrekin bizitzea bultzatuz, azken batean, elkarrekin biziz, ezagutuz, aurreiritzi eta estereotipo asko deuseztatzeko aukera dago, edo behintzat zalantzatzekoa.

Praktikak gauzatzen joan nintzen heinean ohartu nintzen, edonor, gutako nornahi, edozein momentutan, egoera horretan bertan aurki gaitezkeela, eta beraz, lagundu, antzeman eta errespetatu behar ditugula.

Esperientzia pertsonalak eta hezkuntza esperientziak laguntzen dute pobrezia egoeran bizi direnenganako hurbilketa honetan. Ezagutza horiek guztiak jarrera aporofoboak eta diskriminatzaileak gainditzeko beste bide bat direla aipatzen dute, buruz buruko kontaktuak loturak sortzea ekar dezakeelako eta, era horretan, beste modu batera pentsatzeko aukera ekar dezake. Hortik aurrera, bidea argia da: beste modu batera ekiteko moduak edo eta aukerak sortu.
Horretarako, ezinbestekoa da jarrera enpatikoak garatzea. Ez bakarrik lanbidearen esparruan, baita bizitza pertsonalean ere. Gaitasun enpatikoaren bidez, bestearen historian egokiago kokatzeko aukera izango dute; norberak duen historiaren arrazoiak ulertzeko eta hartutako erabakiak aintzat hartzeko. Gaitasun enpatikoaren bidez, beldurra eta lotsa garaitzeko beste modu bat dugu:

Enpatiak laguntzen dit ulertzen beste pertsona nola sentitu daiteken baztertu egiten denean, berekiko arbuiatze-jarrerak edo gorroto jarrerak ditugunean.

\subsection{Azkenik, emozioen atalean ondorengo ondorio hauek kokatu ditzakegu}

Norberak aporofobiaren errealitatearen aurrean eta, are gehiago, aurreiritzi eta estereotipo horiek ere dituela konturatzeak sortzen duen emozioen aurrean kokatzen dira ikasleak:

Lan hau burutzean pertsona txarra sentitu naiz hainbat alditan.

Lehenik eta behin, emozioak ezagutu eta antzeman behar dira ondoren emozio horien kontrola esku artean izateko. Ikasleak pobretuenganako emozio negatibo horiek badituztela konturatzen direnean, horiek aldatzeko kontzientzia hartzen doaz. Ezagutu eta antzeman, aldatzeko.

Eskolan nabarmena da ikasleek beraien emozioak izendatzeko dituzten zailtasunak. Horrexegatik ulertzen dugu gure hezitzaile izatearen atal nagusietakoa hau dela: ikasleengan emozioen hiztegia garatzea; emozioen inguruan hitz egitea. Bizi dugun errealitatea, gure bizitza osoa, emozioetara eramaten dugunean (ez bertan geratzeko, soilik, baina bai bertatik pasatzeko) ditugun jokabideen aldaketa emango da; jokabideak deseroso uzten gaituztenean, bederen.

Ikasleek, ikasketa esanguratsutzat hartzen dute, pobrezia egoera pairatzen duten pertsonenganako aurreiritzi eta estereotipoek sortzen dizkieten emozioen inguruan hitz egiteko gai izatea: idatziz, lan akademiko bat egiterakoan (irakasleak irakurri eta epaituko duen lana izanik) eta baita taldean ere, bere ikaskideekin batera, hauen aurrean:

Ez da erraza nik neure estereotipo eta aurreiritzien inguruko gogoeta bat gauzatzea, pertsonalki asko kostatzen zait nire pertsonaz mintzatzea; eta are gehiago nire estereotipo eta aurreiritzien inguruan hitz egitea, ezaugarri negatiboak baitira. Hala ere, horrelako lan motek neure burua ezagutaraztera naramate, ikaskuntza sakonagoa izanez.

Bazterkeria egoeran dauden pertsonenganako bazterketa emozioak izan dituztela onartzea, kosta ala kosta, garrantzitsua dela baloratzen dute. Idatziz emozio horiek guztiak plazaratzeak, horiekin 
konektatzea eta norberarenak direla aitortzea ahalbidetu die. Hau guztia ezinbestekotzat hartzen dute aurrez sortuak dituzten ideia horiek aldatzeko. Berriro ere, identifikatu, onartu eta aldatu.

Nik nahi ala ez, nire bizitzan presente dagoen sentimenduetako bat da aporofobia.

Min egiten dit onartzea baina, bai, kalean bizi direnenganako errefusa sentitu dut.

Kalean bizi den pertsonari ez begiratzea eta kontaktua saihesteko beharra sentitu dut. Ez nago harro honetaz.

Etxerik gabeko pertsonengana dudan beldurraz konturatzeak, beraiei gorrotoa eta errefusa transmititu diezaiekedala ohartarazteko balio izan dit, nik nahigabe ere.

Bestalde, ikasleek ikusi dute hauek guztiak jaso eta norbere buruari begiratzeko unea ere iritsi dela: laster profesionalak izango dira. Eta nabarmena da: gizarte langileak pobretuekin, baztertuekin, gaixoekin ere lan egin beharko du. Beraz, ezinbestean ikusi dute jarrera horiek aldatzeko estrategien beharra:

Zergatik egoera berean dauden pertsona guztiak berdin kalifikatzen ditugu? Pertsona bakarra dela badakigu zergatik alderatzen ditugu? Zergatik diogu beldurra ezezagunari? Galdera hauek egingo dizkiot neure buruari eta erantzuna bilatzen saiatu esku-hartze prozesuan eta harremanean estereotipo eta aurreiritzi horiek eragina izan ez dezaten. Irakasgai honetan ikasi dudana praktikan jarriko dut.

Hala ere, lan honek ez nau pertsona hobeagoa egin -helburua hori ez den arren-, baina progresiboki nire izaera aldatuko badu, bejondeiola. Azken finean, nire helburua pertsonei laguntzea da, dituzten arazoei irtenbideak aurkitzea eta berdintasun printzipioa sustatzea. Horren haritik, lan hau oso eraginkorra izan dela esango nuke. 


\section{Bibliografía referenciada}

ANDRADE, M. (2008): “¿Qué es la aporofobia? Un análisis conceptual sobre prejuicios, estereotipos y discriminación hacia los pobres", Agenda Social, vol. 2, 117-139 or.

BAUMAN, Z. (2005): Vidas desperdiciadas. La modernidad y sus parias, Bartzelona, Paidós.

BAYÓN, M.C. (2013): "Hacia una sociología de la pobreza: la relevancia de las dimensiones culturales", Estudios Sociológicos de El Colegio de México, XXXI. bol., 91. zb.

CORTINA, A. (2017): Aporofobia, el rechazo al pobre. Un desafío para la democracia, Bartzelona, Paidós.

EXPÓSITO MARÍN, A. J. (2016): “Una aproximación a la aporofobia institucionalizada", in DÍAZ CANO, E. eta BARBIETO, R. L. (koord.), XIV Premio de Ensayo Breve 'Fermín Caballero', Toledo,
Asociación Castellano-Manchega de Sociología, $73-89$ or.

GLUCKSMANN, A. (2005): El discurso del odio, Madril, Taurus.

KOFMAN, F. (2001): Metamanagement. La nueva conciencia de los negocios: cómo hacer de su vida profesional una obra de arte, Buenos Aires, Granica.

MARTÍNEZ NAVARRO, E. (2002): “Aporofobia”, in CONILL, J. (koord.), Glosario para una sociedad intercultural, Valentzia, Bancaja, 17-23 or.

SENNETT, R. (1998): La corrosión del carácter. Las consecuencias personales del trabajo en el nuevo capitalismo, Bartzelona, Anagrama.

- (2003): El respeto. Sobre la dignidad del hombre en un mundo de desigualdad, Bartzelona, Anagrama. 